\title{
Chemical Constituents of Psacalium sinuatum
}

\author{
Amira Arciniegas, ${ }^{1}$ Ana L. Pérez-Castorena, ${ }^{* 1}$ Antonio Nieto-Camacho, ${ }^{1}$ José Luis Villaseñor, ${ }^{2}$ and \\ Alfonso Romo de Vivar $^{1}$ \\ ${ }^{1}$ Instituto de Química, ${ }^{2}$ Instituto de Biología, Universidad Nacional Autónoma de México, Circuito Exterior, Ciudad \\ Universitaria, Coyoacán 04510, D.F., México. Tel: +(5255)-5622-4412, Fax: +(5255)-5622-2217. alperezc@servidor.unam.mx
}

Received October 15, 2009; accepted January 21, 2010

\begin{abstract}
A chemical study of Psacalium sinuatum afforded the furanoeremophilane decompostine, the modified eremophilanes: cacalol, cacalol acetate, dehydrocacalol, maturinin, cacalohastin, dehydrocacalohastin, adenostin B, cacalone-epi-cacalone mixture, dimaturin, adenostylide, radulifolin $\mathrm{F}$, and epi-radulifolin $\mathrm{F}$, in addition to hyperin, sucrose and a mixture of sitosterol-stigmasterol. Extracts and isolated compounds were tested for anti-inflammmatory activity. The hexanic extract of root showed a dose dependent activity $\left(\mathrm{IC}_{50} 0.20\right.$ $\mathrm{mg} / \mathrm{ear}$ ).
\end{abstract}

Key words. Psacalium, Asteraceae, Senecioneae, Tussilagininae, Modified Eremophilanes, Anti-inflammatory Activity.

\section{Introduction}

The genus Psacalium (Asteraceae, Senecioneae, Tussilagininae) groups 40 species of perennial herbs disseminated from the south of the United States to Guatemala [1]. P. sinuatum is one of the six species included into the Matarique medicinal plant complex which is used in Mexico by the Tarahumara ethnia to cure diabetes, renal and hepatic problems [2]. So far, seven species of Psacalium have been chemically studied. Four of them: P. decompositum, P. tussilaginoides (studied as Cacalia decomposita and C. ampulacea, respectively) [3-5], P. radulifolium [6] and $P$. beamanii [7] afforded cacalol derivatives and some eremophilanes mainly. The fifth, $P$. paucicapitatum [8] produced furanoeremophilanes and eremophilanolides, and the other two, P. megaphyllum [9] and P. peltatum (with only the aqueous extract studied) [10] yielded only a flavonoid glycoside and an ulopyranose, respectively. Several biological activities from species of Psacalium have been reported, thus, the hypoglycemic activity of the root water decoction of $P$. decompositum and the anti-hyperglycemic activity of some eremophilanolides isolated from this species is well documented $[5,11]$. A hypoglycemic carbohydrate has been isolated from P. peltatum [10]. Cacalol has been detected as the major active compound in the antioxidant and antimicrobial evaluations of $P$. radulifolium $[6,12]$. The anti-inflammatory activity of cacalol, cacalone [13], cacalohastin and radulifolin F [14] has also been reported. As continuation of our survey on Senecioneae we report the chemical composition of $P$. sinuatum, which to the best of our knowledge has no previous studies. An evaluation of the anti-inflammatory activity of extracts and isolated compounds on 12-O-tetradecanoylphorbol-13-acetate (TPA) model of induced acute inflammation is also included.
Resumen. Por medio de un estudio químico de Psacalium sinuatum se aislaron el furanoeremofilano decompostina, los eremofilanos modificados: cacalol, acetato de cacalol, deshidrocacalol, maturinina, cacalohastina, deshidrocacalohastina, adenostina B, mezcla de cacalona-epi-cacalona, dimaturina, adenostilida, radulifolina F, y epi-radulifolina $\mathrm{F}$, además de hiperina, sacarosa y mezcla de sitosterol-estigmasterol. Los extractos y los compuestos aislados fueron sometidos a pruebas de actividad anti-inflamatoria. El extracto hexánico de raíz presentó actividad dependiente de la dosis ( $\mathrm{IC}_{50} 0.20 \mathrm{mg} /$ oreja).

Palabras clave: Psacalium, Asteraceae, Senecioneae, Tussilagininae, eremofilanos modificados, actividad anti-inflamatoria.

\section{Results and Discussion}

The chemical study of roots and aerial parts of Psacalium sinuatum afforded the furanoeremophilane decompostine (1) [7], the modified eremophilanes: cacalol (2) [15], cacalol acetate (3) [16], dehydrocacalol (4) [17], maturinin (5) [3] , cacalohastin (6), dehydrocacalohastin (7) [18], adenostin B (8) [19], a 1:1 mixture of cacalone (9) and epi-cacalone (10) [5], dimaturin (11) [3], adenostylide (1:1 mixture of $\mathbf{1 2}$ and 13) [19], radulifolin $\mathrm{F}(\mathbf{1 4})$, and epi-radulifolin $\mathrm{F}$ (15) [6], in addition to hyperin (16) [20], sucrose and a mixture of sitosterol-stigmasterol. Structures of the isolated compounds were determined by comparison of their physical constants and spectroscopic data with those reported in the literature.

Nearly all the compounds isolated from $P$. sinuatum are modified eremophilane derivatives oxygenated at positions 8 and 9 (2-15), which have also been reported as the more abundant metabolites in four of the six Psacalium species studied so far: P. decompositum, P. tusilaginoides [3-5], P. radulifolium [6], and P. beamanii [7]. Pyrrolizidine alkaloids, also common in Senecioneae, have not been found in Psacalium, with the only exception of $P$. decompositum in whose aqueous extract these alkaloids were detected by TLC [5]. In summary, even though five out the seven species of Psacalium studied so far have shown a similar composition, at this point, it is not possible to establish a chemical profile of the genus with only $17.5 \%$ of the species studied.

On the other hand, the anti-inflammatory activity of the hexanic, acetonic and methanolic extracts of roots and aerial parts, as well as that of the isolated compounds was tested on 12-O-tetradecanoylphorbol-13-acetate (TPA) model of induced acute inflammation [22] (Table 1). The hexanic extract of roots showed a maximal edema inhibition of $77.98 \%$ in a topical 



$12 \mathrm{R}=\mathrm{CH}_{3}, \mathrm{R}_{1}=\mathrm{OH}$ $13 \mathrm{R}=\mathrm{OH}, \mathrm{R}_{1}=\mathrm{CH}_{3}$



$2 \mathrm{R}=\mathrm{OH}$ $3 \mathrm{R}=\mathrm{OAc}$ $4 \mathrm{R}=\mathrm{OH}, \Delta^{1,2}$

$$
6 \mathrm{R}=\mathrm{OCH}_{3}, \Delta^{1,2}
$$<smiles>[R]C1CCC2=C(C1C)C([R])([R])c1c(C)coc1C2=O</smiles>

$9 \mathrm{R}=\mathrm{CH}_{3}, \mathrm{R}_{1}=\mathrm{OH}, \mathrm{R}_{2}=\mathrm{H}$ $10 \mathrm{R}=\mathrm{OH}, \mathrm{R}_{1}=\mathrm{CH}_{3}, \mathrm{R}_{2}=\mathrm{H}$ $14 \mathrm{R}=\mathrm{CH}_{3}, \mathrm{R}_{1}=\mathrm{OH}, \mathrm{R}_{2}=$ OGluc $15 \mathrm{R}=\mathrm{OH}, \mathrm{R}_{1}=\mathrm{CH}_{3}, \mathrm{R}_{2}=$ OGluc
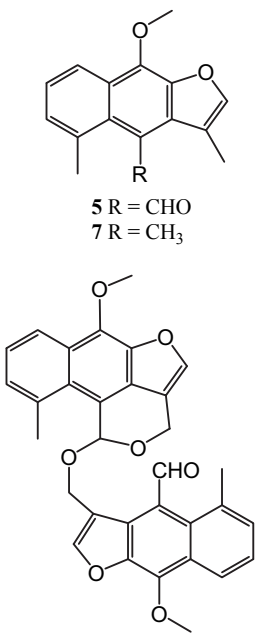

11

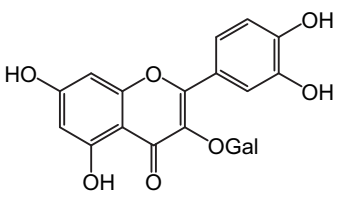

administration of $1 \mathrm{mg} / \mathrm{ear}$, this activity was dose dependent with a $\mathrm{IC}_{50}$ of $0.2 \mathrm{mg} / \mathrm{ear}$ (Table 2). Indomethacin, the reference compound, produced $87.61 \%$ of edema inhibition at the same doses ( $1 \mathrm{mg} / \mathrm{ear}$ ), but considering its $\mathrm{IC}_{50}$ of $0.1 \mathrm{mg} / \mathrm{ear}$, it was twice as active. The root extracts were always more active than the respective extracts of aerial parts; the activity in both, roots and aerial parts, decreases with the increase in the polarity of the extract (Table 1).

Among the tested compounds, the mixture of cacalone (9) and epi-cacalone (10) was more active than cacalol (2), in concordance with literature [13]. In the compounds with cacalol skeleton, the activity decreases from $38.61 \%$ in cacalol (2) to $31.14 \%$ in cacalol acetate (3) and to $10.84 \%$ in cacalohastine (6), suggesting that somehow the free hydroxy group is important in the edema inhibition. Moreover, the increase in activity to $59.40 \%$ observed in dehydrocacalol (4) may imply that planarity could also affect the inflammatory response, since dehydrocacalohastine (7) showed higher activity (35.80\%) than cacalohastine (6) $(10.84 \%)$. In the case of the mixture of cacalone (9) and epi-cacalone (10) the activity (50.33\%) diminished with the presence of a glucosyloxy group in radulifolin $\mathrm{F}(\mathbf{1 4}, \mathbf{2 1 . 0 9 \% )}$ ) and epi-radulifolin $\mathrm{F}(\mathbf{1 5}, 13.74 \%)$.

Table 1. Effect of extracts and compounds isolated from P. sinuatum on TPA-induced mouse edema

\begin{tabular}{|c|c|c|c|}
\hline Sample & Dose (mmol / ear) & Edema (mg) & Inhibition (\%) \\
\hline Hexanic extract of roots ${ }^{b}$ & $1.0^{\mathrm{a}}$ & $3.14 \pm 0.31^{* *}$ & $77.98^{* *}$ \\
\hline Acetonic extract of roots ${ }^{\mathrm{c}}$ & $1.0^{\mathrm{a}}$ & $5.03 \pm 2.38^{*}$ & $56.73^{*}$ \\
\hline Methanolic extract of roots ${ }^{c}$ & $1.0^{\mathrm{a}}$ & $8.53 \pm 1.98$ & 26.65 \\
\hline Hexanic extract of aerial parts ${ }^{b}$ & $1.0^{\mathrm{a}}$ & $4.93 \pm 1.74 * *$ & $59.40^{* *}$ \\
\hline Acetonic extract of aerial parts ${ }^{\mathrm{c}}$ & $1.0^{\mathrm{a}}$ & $8.80 \pm 1.21^{* *}$ & $27.54 * *$ \\
\hline Decompostin $(\mathbf{1})^{\mathrm{b}}$ & 1.0 & $7.67 \pm 1.91^{*}$ & $36.90^{*}$ \\
\hline Cacalol $(2)^{\mathrm{d}}$ & 1.0 & $9.43 \pm 0.29 *$ & $38.61^{*}$ \\
\hline Cacalol acetate $(3)^{\mathrm{b}}$ & 1.0 & $8.37 \pm 1.88^{*}$ & $31.14^{*}$ \\
\hline Dehydrocacalol $(4)^{b}$ & 1.0 & $4.93 \pm 1.23 * *$ & $59.40 * *$ \\
\hline Adenostin B $(\mathbf{8})^{\mathrm{b}}$ & 1.0 & $6.10 \pm 2.09^{* *}$ & $49.79 * *$ \\
\hline Cacalone/epi-cacalone $(\mathbf{9} / \mathbf{1 0}, 1: 1)^{\mathrm{d}}$ & 1.0 & $7.63 \pm 1.62 * *$ & $50.33^{* *}$ \\
\hline Dimaturin $(\mathbf{1 1})^{\mathrm{b}}$ & 1.0 & $5.83 \pm 1.30^{* *}$ & $52.02 * *$ \\
\hline Adenostylide $(\mathbf{1 2} / \mathbf{1 3} 1: 1)^{\mathrm{b}}$ & 1.0 & $5.33 \pm 2.12^{* *}$ & $56.10^{* *}$ \\
\hline Radulifolin F (14) ${ }^{\mathrm{e}}$ & 1.0 & $10.27 \pm 0.62 *$ & $21.09 *$ \\
\hline Epi-radulifolin $\mathrm{F}(\mathbf{1 5})^{\mathrm{e}}$ & 1.0 & $11.67 \pm 0.35$ & 13.74 \\
\hline Hyperin $(\mathbf{1 6})^{\mathrm{e}}$ & 1.0 & $13.10 \pm 0.71$ & 3.14 \\
\hline Indomethacin ${ }^{\mathrm{f}}$ & $1.0^{\mathrm{a}}$ & $2.06 \pm 0.30 * *$ & $87.61 * *$ \\
\hline Indomethacin ${ }^{\mathrm{f}}$ & 1.0 & $1.99 \pm 0.69^{*}$ & $83.73 *$ \\
\hline
\end{tabular}

Each value represents the mean of three animals \pm standard error. ${ }^{a}$ Dose $\mathrm{mg} /$ ear. Control: bacetone- $\mathrm{CH}_{2} \mathrm{Cl}_{2} 1: 1,12.15 \pm 0.98$; ${ }^{\mathrm{c}}$ methanol, $11.63 \pm 0.24$; ${ }^{\mathrm{d}}$ acetone$\mathrm{CH}_{2} \mathrm{Cl}_{2} 1: 1,15.37 \pm 1.85$, ${ }^{\mathrm{e}}$ acetone, $13.53 \pm 104$; ${ }^{\mathrm{f}}$ ethanol-acetone $1: 1,15.00 \pm 0.47$. Results were analysed by the $t$ Student test. ${ }^{*} \mathrm{p} \leq 0.05 . * * \mathrm{p} \leq 0.01$. 
Table 2. Dose response evaluation of the hexanic extract of roots of $P$. sinuatum

\begin{tabular}{|c|c|c|c|c|}
\hline Control & & $14.26 \pm 0.99$ & & \\
\hline \multirow[t]{3}{*}{ Hexanic extract of roots } & 0.031 & $12.34 \pm 1.36$ & 13.46 & $0.20 \mathrm{mg} /$ ear \\
\hline & 0.1 & $8.38 \pm 1.07 * *$ & $41.23 * *$ & $\mathrm{r}=0.97$ \\
\hline & 0.31 & $6.86 \pm 1.33 * *$ & $51.89 * *$ & \\
\hline \multirow[t]{3}{*}{ Indomethacin } & 0.036 & $11.83 \pm 0.70^{*}$ & $21.11^{*}$ & $0.10 \mathrm{mg} / \mathrm{ear}$ \\
\hline & 0.11 & $6.82 \pm 1.27 * *$ & $54.53 * *$ & $\mathrm{r}=0.99$ \\
\hline & 0.357 & $1.99 \pm 0.68 * *$ & $83.73 * *$ & \\
\hline
\end{tabular}

Each value represents the mean of five animals \pm standard error. Results were analysed by the analysis of variance ANOVA followed by Dunnett test. $* \mathrm{p} \leq 0.05$. $* * \mathrm{p} \leq 0.01$

\section{General Experimental Procedures}

Melting points were determined on a Fisher Jones melting point apparatus and are uncorrected. IR spectra were recorded on a Nicolet Magna-IR 750 spectrometer. EIMS data were determined on a JEOL JMS-AX505HA mass spectrometer at $70 \mathrm{eV} .{ }^{1} \mathrm{H}$ NMR and ${ }^{13} \mathrm{C}$ NMR data were obtained on a Varian Unity 300 or on a Varian Unity Plus 500 instrument. Chemical shifts were referred to TMS $(\delta 0)$. Column chromatography (VCCs) was performed under vacuum using Silica gel 60 G (Merck, Darmstadt, Germasny). Flash column chromatography (FCC) was performed on silica gel 60 (230-400 Macherey-Nagel). TLC was carried out on Silica gel $60 \mathrm{GF}_{254}$ and preparative TLC on Silica gel $\mathrm{GF}_{254}$ (Macherey-Nagel), layer thickness $2.0 \mathrm{~mm}$.

\section{Plant Material}

Psacalium sinuatum (Cerv.) H. Rob. \& Bretell was collected $6 \mathrm{~km}$ northeast of Canoas, Nayarit, México, in September 2007. A voucher specimen was deposited at the Herbarium del Instituto de Biología, UNAM, México (MEXU 1213451).

\section{Extraction and Isolation}

Dried and ground roots (130 g) and aerial parts (276 g) of $P$. sinuatum were separately and successively extracted with hexane, acetone and methanol. Solvents were removed at reduced pressure to obtain the respective extracts which gave negative the Dragendorff's alkaloids test. The hexanic extract of roots $(6.0 \mathrm{~g})$ was submitted to vacuum column chromatography (VCC) using hexane-EtOAc mixtures as gradient elution system to afford fractions A-C. Fraction A (1.8 g) was purified by a VCC eluted with hexane-EtOAc mixtures of increasing polarity to obtain from fractions eluted with hexane: cacalo- hastine $(6,48 \mathrm{mg}, 0.04 \%), \mathrm{mp} 82-84^{\circ}$ (lit. 84.0-85.5 $)$ [18], dehydrocacalohastine $(7,30 \mathrm{mg}, 0.02 \%)$, mp 73-75 (lit. $\left.71.0-77.3^{\circ}\right)$ [18], and cacalol acetate $(3,23 \mathrm{mg}, 0.02 \%), \mathrm{mp}$ $101-102^{\circ}$ (lit. $105^{\circ}$ ) [16]. The same column produced from fractions eluted with hexane-EtOAc 49:1, adenostin B $(\mathbf{8}, 80$ $\mathrm{mg}, 0.06 \%$ ), mp $208-209^{\circ}$ (lit. 202-205) [19] and those fractions eluted with hexane-EtOAc 19:1 afforded a 1:1 mixture of cacalone (9) and epi-cacalone (10) (302 mg, $0.23 \%$ ), mp $115-117^{\circ}$ (lit. $115-118^{\circ}$ ) [5, 12]. Fraction B (2.5 g) was submitted to flash column chromatography (FCC) eluted with hexane-EtOAc 49:1 to obtain cacalol (2, $180 \mathrm{mg}, 0.14 \%)$, mp $90-91^{\circ}$ (lit. 90-92 ${ }^{\circ}$ [12, 15] and maturinin $(\mathbf{5}, 10 \mathrm{mg}, 0,01 \%)$, mp 95-96 (lit. 95-96 ${ }^{\circ}$ ) [3]. From fraction C decompostin (1, $330 \mathrm{mg}, 0.25 \%$ ), mp 192-194 (lit. 195-196) [7] was isolated. Purification of its mother liquors $(1.8 \mathrm{~g})$ by FCC eluted with hexane-EtOAc 9:1 produced fractions D and E. Fraction D (350 mg) was submitted to FCC eluted with hexane-acetone 19:1 to obtain a $1: 1$ mixture of $\mathbf{9}$ and $\mathbf{1 0}(130 \mathrm{mg}, 0.1 \%)$. Purification of fraction E $(220 \mathrm{mg})$ by FCC eluted with hexane-EtOAc 19:1 produced dimaturin (11, $30 \mathrm{mg}, 0.02 \%)$, mp $199-201^{\circ}$ (lit. 201-203 ${ }^{\circ}$ [3], and 1 (50 mg, 0.04\%). The acetonic extract of roots $(3.0 \mathrm{~g})$ afforded fractions $\mathrm{F}$ and $\mathrm{G}$ by VCC using hexane-EtOAc as elution solvent. Fraction F (300 $\mathrm{mg}$ ) was purified by FCC eluted with hexane-EtOAc 49:1 to obtain 3 (40 mg, 0.03\%) and 2 (83 mg. 0.06\%). From fraction $\mathrm{G}$ (500 mg), compound 3 (10 mg, 0.01\%) and adenostylide (1:1 mixture of 12 and 13, $16 \mathrm{mg}, 0.01 \%$ ), mp 138-140 (lit. $140-141^{\circ}$ ) [19] were isolated by FCC eluted with hexaneEtOAc 19:1. The methanolic extract of roots $(8.0 \mathrm{~g})$ was purified by VCC using EtOAc-MeOH mixtures of increasing polarity. Fractions obtained with EtOAc-MeOH 49:1 (600 $\mathrm{mg}$ ) were further purified by $\mathrm{VCC}$ eluted with $\mathrm{CH}_{2} \mathrm{Cl}_{2}-\mathrm{MeOH}$ $85: 15$ to afford fraction $\mathrm{H}(98 \mathrm{mg}$ ) which was purified by preparative TLC eluted three times with $\mathrm{CH}_{2} \mathrm{Cl}_{2}-\mathrm{MeOH}$ 9:1 to produce radulifolin $\mathrm{F}(\mathbf{1 4}, 13 \mathrm{mg}, 0.01 \%$, colorless oil) and epi-radulifolin F $(\mathbf{1 5}, 11 \mathrm{mg}, 0.01 \%$, colorless oil) [6]. The hexanic extract of the aerial parts $(5.0 \mathrm{~g})$ was purified by two 
successive chromatographies using hexane-EtOAc mixtures as elution solvents to produce $2(85 \mathrm{mg}, 0.03 \%), 3(42 \mathrm{mg}$, $0.02 \%$ ), dehydrocacalol $\left(4,30 \mathrm{mg}, 0.01 \%\right.$ ), $\mathrm{mp} 120-122^{\circ}$ (lit. $\left.124-125^{\circ}\right)$ [17] and $180 \mathrm{mg}(0.07 \%)$ of a mixture sitosterolstigmasterol. Purification of the acetonic extract of aerial parts ( $8.5 \mathrm{~g}$ ) by VCC using hexane-EtOAc gradient mixtures, followed by a FCC eluted with hexane-EtOAc 49:1 led to the isolation of 1 ( $80 \mathrm{mg} 0.03 \%), 2$ (60 $\mathrm{mg}, 0.02 \%)$ and 3 (90 $\mathrm{mg}, 0.04 \%)$. The methanolic extract of aerial parts $(24 \mathrm{~g})$ was subjected to VCC eluted with EtOAc- $\mathrm{MeOH}$ in increasing gradient. Fractions eluted with EtOAc-MeOH 8:2 (12 g) were purified successively by VCC eluted with $\mathrm{CH}_{2} \mathrm{Cl}_{2}-\mathrm{MeOH}$ 9:1 and a Sephadex LH-20 column eluted with $\mathrm{MeOH}-\mathrm{H}_{2} \mathrm{O}$ 9:1 to produce hyperin $(\mathbf{1 6}, 450 \mathrm{mg}, 0.16 \%)$, mp $243-245^{\circ}$ (lit. 238$\left.240^{\circ}\right)[20,21]$ and sucrose $1.5 \mathrm{~g}(0.54 \%)$.

\section{Evaluation of the anti-inflammatory activity}

Animals: Male NIH mice weighing 25-30 g were maintained in standard laboratory conditions in the animal house (temperature $27 \pm 1{ }^{\circ} \mathrm{C}$ ) in a 12/12 h light-dark cycle, according with the Mexican official norm MON-062-Z00-1999. They were fed laboratory diet and water ad libitum.

\section{TPA-induced edema model}

The TPA-induced ear edema assay in mice was performed as previously reported [22]. A solution of TPA $(2.5 \mu \mathrm{g})$ in EtOH $(10 \mu \mathrm{l})$ was applied topically to both faces $(5 \mathrm{ml}$ each fase) of the right ear of the mice, 10 min after solutions of the test substances in their respective solvents (Table 1) were applied (10 $\mu \mathrm{l}$ each fase). The left ear received ethanol $(10 \mu \mathrm{l})$ first, and $20 \mathrm{ml}$ of the respective solvent subsequently. Four hours later the mice were killed by cervical dislocation. A $7 \mathrm{~mm}$ diameter plug was removed from each ear. The swelling was assessed as the difference in weight between the left and the right ear. Control animals received the correspondent solvent in each case. Edema inhibition (EI \%) was calculated by the equation: $\mathrm{EI}=100-(\mathrm{B} \times 100 / \mathrm{A})$, where $\mathrm{A}$ is the edema induced by TPA alone and $\mathrm{B}$ is the edema induced by TPA plus sample. Indomethacin was used as the reference compound (Tables 1,2)

\section{Acknowledgements}

We are indebted to Ma. de los Angeles Peña, Elizabeth Huerta, María Isabel Chávez, Héctor Ríos, Beatriz Quiroz, Nieves Zavala, Rocío Patiño, Javier Pérez, Luis Velasco, and Gabriela Salcedo for technical assistance.

\section{References}

1. Barkley, T. M.; Clark, B. L.; Fuston. A. M. Compositae: Systematics. Proceedings of the International Compositae Conference, Kew, 1994. Hind, D. J. N., Ed. Royal Botanical Gardens Kew, 1996, Vol 1, pp. 613-620.

2. Linares, E.; Bye, R. J. Ethnopharmacol. 1987, 19, 153-186.

3. Correa, J.; Romo, J. Tetrahedron 1966, 22, 685-691.

4. Joseph-Nathan, P.; Negrete, M. C.; González, M. P. Phytochemistry 1970, 9, 1623-1628.

5. Inman, W. D.; Luo, J.; Joload, S. D.; King, S. R.; Cooper, R. J. J. Nat. Prod. 1999, 62, 1088-1092.

6. Garduño-Ramírez, M. L.; Delgado, G. Rev. Soc. Quím. Méx. 2003, 47, 160-166.

7. Pérez-Castorena, A. L.; Arciniegas, A.; Villaseñor, J. L.; Romo de Vivar, A. Rev. Soc. Quím. Mex. 2004, 48, 21-23.

8. Burgueño-Tapia, E.; Hernández-Carlos, B.; Joseph-Nathan, P. J. Mol. Struct. 2006, 825, 115-123.

9. Pérez-Castorena, A. L.; Castro, A.; Romo de Vivar, A. Phytochemistry 1997, 46, 1297-1299.

10. Contreras, C.; Román, R.; Pérez, C.; Alarcón, F.; Zavala, M.; Pérez, S. Chem. Pharm. Bull. 2005, 53, 1408-1410.

11. Alarcón-Aguilar, F. L.; Jiménez-Estrada, M.; Reyes-Chilpa, R.; González-Paredes, B.; Contreras-Weber, C. C.; Román-Ramos, R. J. Ethnopharmacol. 2000, 69, 207-215.

12. Garduño-Ramírez, M. L.; Trejo, A.; Navarro, V.; Bye, R.; Linares, E.; Delgado, G. J. Nat. Prod. 2001, 64, 432-435.

13. Jiménez-Estrada, M.; Reyes Chilpa, R.; Ramírez Apan, T.; Lledias, F.; Hansberg, W.; Arrieta, D.; Alarcón Aguilar, F. J. J. Ethnopharmacol. 2006, 105, 34-38.

14. Acevedo-Quiroz, N.; Domínguez-Villegas, V.; Garduño-Ramírez, M. L. Nat. Prod. Comm. 2008, 3, 313-317.

15. Kedrowski, B. L.; Hoppe, R.W. J. Org. Chem. 2008, 73, 51775179.

16. Bohlmann, F.; Zdero, C. Phytochemistry 1978, 17, 1135-1153.

17. Kakisawa, H.; Inouye, I. Tetrahedron Lett. 1969, 24, 1929-1932.

18. Hayashi, K.; Nakamura, H.; Mitsuhashi, H.; Phytochemistry 1973, 12, 2931-2933.

19. Kuroyanagi, M.; Naito, H.; Noro, T.; Ueno, A.; Fukushima, S. Chem. Pharm. Bull. 1985, 33, 4792-4797.

20. Markham, K. R.; Ternai, B.; Stanley, R.; Geiger, H.; Mabry, T. J. Tetrahedron 1978, 34, 1389-1397.

21. Rizk, A. M. Planta Med. 1979, 36, 189-190

22. Pérez-Castorena, A. L, Arciniegas, A.; Ramírez-Apan, M. T.; Villaseñor J. L.; Romo de Vivar, A. Planta Med. 2002, 68, 645647. 